\title{
PJIEE
}

Premise : Journal of English Education and Applied Linguistics

https://fkip.ummetro.ac.id/iournal/index.php/english

Refai

\section{USING AUTHENTIC LISTENING MATERIALS IN EFL CLASSROOM: STUDENTS' PERCEPTIONS IN INDONESIAN CONTEXT}

\author{
by \\ Refai \\ English Department of Universitas Muhammadiyah Metro \\ E-mail: refaiummetro@gmail.com
}

Received: August 30, 2017

Revised: January 20, 2018

Accepted: February 24, 2018

Published: April 2, 2018

\begin{abstract}
:
Instructing listening comprehension to EFL students need good plannings. Authentic listening materials as a strategic teaching media are best utilized by English instructors to facilitate the EFL students' listening comprehension in classrooms and language laboratory. Applying authentic listening materials as teaching media in listening practice activites are challenged to bridge EFL students and not only enhancing their listening skill but also improving and developing their knowledge of the real life, culture, and social affairs of English native speakers. The source of authentic listening materials applied in the subject class are mostly taken from youtube.com. A popular open source website which provide online videos. The aim of the study was to find out EFL students' attitudes and perceptions when and after using the authentic videos in an EFL listening class. The participants of the study were the second semester EFL students of English Language Teaching department in Universitas Muhammadiyah Metro Indonesia. The data were gathered from a questionnaire and open interviews. It is found out that most of EFL students who were instructed by the authentic videos show positive attitudes and have good perceptions in utilizing youtube videos as one of the alternative authentic materials in comprehending English utterances.
\end{abstract}

Keywords: EFL students' attitude, EFL students' perception, Listening skill, Youtube videos

\section{INTRODUCTION}

Listening is one of the four important skills in learning a language. Normal learners' listening skill can only be developed by exposing them to the spoken target language

effectively. The exposure process is formally wrapped in language instruction. Instructing 
listening to EFL students need properly preparations. As well, the teacher him/herself must patiently encourage his/her EFL students to grasp information and respond the spoken language directly without any transcriptions in order to make them acquiring the skill as natural as children listen and respond to language before they learn to talk.

Although some EFL students said that they have no problems in comprehending the English texts or think easy to speak in English, they mostly meet problems in knowing English utterances, especially in which spoken by native speakers. Most EFL students experience confused to grasp information from the spoken language since naturally native speakers usually speak in various volumes and speeds with frequent interruptions. Further, every native speaker bring his/her own accent into his/her spoken communication to others.

In EFL instructional context, due to hiring native speakers as the native English instructors who may expose the EFL students to listen authentic English utterances directly from them will spend a lot of money, many local EFL teachers take alternative sources to fill the gap one of them is by utilizing authentic materials provided by internet, especially youtube videos. Based on that, this study aimed to investigate the students' attitudes and perceptions on using authentic materials in Indonesian context.

Some scholars define the term authentic materials in various statements. As Nunan (1989, as cited in Adams, 1995) asserts that authentic materials are not always produced for the purpose of language teaching. In addition, Bacon and Finnemann (1990) defines authentic materials as texts produced by and intended for native speakers for nonpedagogical purposes. Polio (2014) supports the definitions about the authentic materials that the authentic materials are not designed officially for teaching and learning purposes. They are written to supply native speakers with real-life information. Polio also adds that there are two kinds of authentic materials, namely written and spoken authentic materials

According to Lingzhu \& Yuanyan (2010), cited in Gebhard (1996) that authentic materials can be classified into three categories:

1. Authentic listening-viewing materials: Television commercials, quiz shows, cartoons, news clips, comedy shows, soap operas, professionally audio-taped short stories and novels, radio ads, songs, documentaries, and sales pitches.

Premise Journal Vol 7 No 1, April 2018, e-ISSN: 2442-482x, p-ISSN: 2089-334, page 22-35 Copyright@2018by PJEE 
2. Authentic visual materials: slides, photographs, paintings, children's artwork, stickfigure drawings, wordless street signs, silhouettes, pictures from magazine, newspaper or internet, ink blots, postcard pictures, Wordless picture books, stamps, and X-rays.

3. Authentic printed materials: newspaper articles, movie advertisements, astrology columns, sports reports, obituary columns, advice columns, lyrics to songs, restaurant menus, street signs, cereal boxes, candy wrappers, tourist information brochures, university catalogs, telephone books, maps, TV guides, comic books, greeting cards, grocery coupons, pins with messages, and bus schedules.

Lingzhu \& Yuanyan (2010) define the authentic listening materials as genuine instanced of language use, like natural conversation among native speakers with spontaneous speech. The authentic listening materials are unscripted, natural, and spontaneous spoken language materials, such as interviews, lectures, dialogs, discussions, and coversations.

The EFL learners need to use the authentic listening materials in order to develop their listening comprehension. Lingzhu \& Yuanyan (2010), Using authentic listening materials may give several advantages to EFL learners, as follows:

\section{A. Training EFL students to listen something from the real language}

The language used in the authentic listening materials is the language used by native speakers in their daily lifes. The EFL learners are encouraged to blend theirselves in the real situations of the native speakers natural conversations or speeches, etc.

\section{B. Increasing the EFL students' motivation}

Authentic listening materials, especially the current popular ones such as clips from media always dealing with topics that are familiar to students and relevant to their personal experience, hence, have been found appealing. Introducing and utilizing natural materials can be a very meaningful experience for students and can capture the interest and stimulate the imagination of students. So, students will be more motivated to learn.

Premise Journal Vol 7 No 1, April 2018, e-ISSN: 2442-482x, p-ISSN: 2089-334, page 22-35 Copyright@2018 by PJEE 


\section{Accumulating students' knowledge}

Authentic listening materials contain quite amount of information covering almost every field in human life. Therefore, using authentic listening materials in EFL listening class may supply students with information and provide students opportunities to improve their knowledge of life.

Recent researchers showed the empirical evidences in their studies that the use of authentic materials in English language teaching classrooms may improve and develop the learners' listening and reading skills in the target language. As Belaid (2015) clarified that all Libyan EFL teachers, despite differences in their teaching experiences and academic degrees all fully advocated using authentic materials in language classes. Teachers preferred to using authentic materials as they realized that using authentic materials would expose students to the everyday real language, as used in the daily life language. In line with that, Omid (2015) pointed out that Iranian teachers had positive attitudes toward providing authentic input in their classes regardless of their teaching experience, and academic degree. He added that such an attitude was to motivate the students to improve their skills and to the real English language. Based on the previous studies, the experience or even unexperience teachers with various academic degrees, they have positive attitudes toward applying the authentic materials in their EFL classroom. The study specifically investigate the students' attitude and perceptions toward the use of authentic listening materials in EFL listening class in Indonesian context.

\section{EFL Listening in Indonesian Context}

L2 listening is regarded as a highly complex process, in which the listener must draw upon a wide variety of knowledge sources, linguistic and non-linguistic, to interpret rapidly incoming data (Buck, 2001). Listening mastery is considered as a big problem for EFL students in enhancing their listening skills. Language learners' troubles with listening include linguistic difficulties such as learning a new phonetic system, inability to parse the L2 speech stream, and struggling to understand the spoken forms of words they know in written form (Goh, 2002).

Premise Journal Vol 7 No 1, April 2018, e-ISSN: 2442-482x, p-ISSN: 2089-334, page 22-35 Copyright@2018 by PJEE 
Cahyono \& Widiati (2009) point out that the success of listening instruction is determined by a number of factors, one of which is the types of materials. in addition, Harmer (2007), cited in Cahyono \& Widiati (2009) classifies listening materials into two types: extensive and intensive listering materials. Extensive listeing is carried out outside the classroom. Therefore, any material available outside the classroom (e.g., radio, TV, personal computer, the internet) can be used for extensive listening. Some of the advantages of extensive listening materials are that students can use them based on their preference and they can use the materials as many times they want. Intensive listening materials (e.g., those stored in tapes, CD, or hard disk) are already available in the classroom or language laboratory. This type of materials can contain various types of texts (e.g., unscripted or natural discourses and scripted or prepared materials). In intensive listening, the students usually listen to the materials at the same time and, if the students do not wear headsets, the voice quality might not be the same for all of the students (Harmer, 2007; cited in Cahyono \& Widiati, 2009).

In Indonesian context, EFL listening can be taught discretely as a particular course, especially, in English departement of Universities and it has certain course names such as Listening or Listening Comprehension. Listening is provided as discrete courses due to the students' needs to listen to various types of English discourses intensively as part fo their curricular activities (Cahyono \& Widiati, 2009).

The study aim is to investigate the EFL students' perceptions and attitudes to using authentic listening materials in EFL classroom. It tries to probe the answers of the following questions:

1. What are the EFL students' attitudes toward using authentic listening materials in EFL listening classes?

2. What are the students' perceptions of using the authentic listening materials in EFL listening classes?

Premise Journal Vol 7 No 1, April 2018, e-ISSN: 2442-482x, p-ISSN: 2089-334, page 22-35 Copyright@2018 by PJEE 


\section{METHODOLOGY}

The participants of the study were the second semester students of English language teaching (ELT) departement in Universitas Muhammadiyah Metro Indonesia. In this study, there were 3 students interviewed and 30 students were given questionnaire to know their perceptions and attitudes toward the use of authentic material in their listening course. The students have been learning English for six years. They spent the first three years learning English in Junior high schools, and the next three years were learnt by the students in senior high schools. As an additional information, most of the authentic materials applied by the lecturer in language laboratory or classroom were downloaded from youtube and instantly used in the teaching activities without any further adaptation. The listening class is held once in a week for one and half hour by using a language laboratory or classroom.

An adapted questionnaire from Hedge (1985:66-67), consisted of 20 items was distributed to $30 \mathrm{EFL}$ students to discover their attitudes and perceptions toward using authentic listening materials in language laboratory and classrom, and an interview guide was also applied to 3 EFL students which recorded by the lecturer as low, medium, and high achievers at the listening class. Utilizing the interview guide is aimed to reconfirm and uncover information deeply about the EFL students' attitudes and perceptions toward using authentic listening materials in the language learning. The data minings were taken for two day, the questionnaire was distributed at the first day and the interviews were undertaken at the second day of the appointment times.

\section{FINDINGS}

Based on the elicited questionnaire distributed to the EFL students, it revealed that most of the EFL students like to listen any English materials. They sometimes enjoy English materials in the forms of films, music shows, news, comedy, and etc. Most of them prefer watching English films and music shows. When they were asked whether they have problem to understand the meanings of some words or phrases almost half of the students reply that to understand the meaning of words and phrases are to become their problems while they were watching English films or another English programs. When they were asked whether they have problem with English grammar, more than half of them said that 
it was also a problem for them. It is also found that only few of them are able to write down anything they have heard in a piece of paper, even to retell it in their own English.

In addition, next questions were to know the EFL students' attitude toward using the authentic listening materials in language laboratory or classroom. They mostly realized that having listening skill is essential in English language learning. More than half of them enjoyed the listening activities, they said that learning listening is fun. Unfortunately, only few of them would use extra time to sharpen their listening skill out of classroom. When they were asked whether they enjoy the listening materials uttered by native speakers, less than half of the students feel enjoyable about the use of the materials in the learning activity, however, they like the way the lecturer manage the class as they mentioned that they mostly like the teaching activities.

The last questions were intended to see the EFL students' perceptions about the use of authentic listening materials in EFL classroom. Half of the class members voted 'agree' that the title selected by the lecturer is intersting. Most of the students agreed that the class activities carried out by the lecturer are interesting. To accomodate the descrepencies between low, medium, and high achievers in learning activities, the lecturer often instructs them to work in pairs or group in solving the problems, and half of the class members 'agree' that it is good for them, they can solve the problem better in groups or pairs. Half of the students agreed that the homework given by the lecturer is demanding. However, the homework is interesting and permitted to solve in groups. All of the students state that applying authentic listening materials in EFL listening class must be continued as they realize that the materials are important to develop their listening comprehension.

Interviews were also conducted in this study in order to probe deeply about using authentic listening materials in EFL classroom. The interview session was presented by three EFL students, they did not involve in fulfilling the questionnaire at the previous day. 


\section{EFL students' attitudes toward using authentic materials in EFL listening classes}

First of all, three EFL students were expected to listen a monologue; it is a long speech made by one person... (http://www.merriam-webster.com/dictionary/monologue), spoken by famous person for about 1 minute : 30 second. After that, the interview begun:

For the past 33 years, I look in the mirror every morning and ask myself, if today were last day of my life, what I wanna do what I am about to do today. And whenever the answer has been known for two many days in row. I know I need to change something. Remembering that all be dead soon is the most important to our life ever encounter to help me make a big choices in life, because almost everything, all external expectations, our pride, our fear embarrasment of failures, these things just fall away in the face of death, leaving only what is trully important, remembering that you're going to die is the best way I know to avoid the traps of thinking you have something to lose, you are already naked, there is no reason not to follow your heart, about a year ago I was diagnosed with cancer, I had scanned 7.30 in the morning and clearly showed a tumor on my pankreas, I don't even know what the pankreas was, the doctors told me this was almost certainly a type of cancer that is incurable that I should expect to live no longer than three to six months, my doctor adviced me to go home and get my affairs in order which is doctor called for prepare to die. It means to try and tell your kids everything you thought you have the next ten years to tell them, it's just a few months. It means to make sure everything is bottomed up, so it will be as easy as possible for your family. It means to say you goodbye

(Steven Paul Jobs, 1955 - 2011)

\section{First Student}

Interviewer: Is the monolog spoken by Indonesian, do you think?

Respondent: No, it is not. It can be an American or British.

\section{Second Student}

Interviewer: Is the monolog spoken by Indonesian, do you think?

Respondent: No, I don't think so. May be an American

\section{Third Student}

Interviewer: Is the monolog spoken by Indonesian, do you think?

Respondent: No, of course not. I am sure, he is an American

Based on the transcriptions of the above conversations that all students know that the speaker of the monologue was not an Indonesian but native speaker. So, it can be concluded that the students implicitly know, the utterance is an authentic material. 


\section{First Student}

Interviewer : What do you think, does the man speak in normal speed or fast speed?

Respondent : ...very fast, I think

Interviewer: Is it difficult to get some messages from the recorded audio?

Respondent: yes, it is difficult

\section{Second Student}

Interviewer : does the man speak in normal speed or fast speed, do you think?

Respondent : I think, he spoke in a normal speed

Interviewer: Is it difficult to get some messages from the recorded audio?

Respondent: yes and no, I mean, I can get few messages from the recorded audio, just few...

\section{Third Student}

Interviewer : do you think, the man speak in fast speed?

Respondent: no, he spoke in normal speed

Interviewer: Can you get some messages from the recorded audio?

Respondent: yes, I mean, I can get few messages from the recorded audio, just few...

I saw various expressions from the three students, the first student looked so confused when she listened the monologue.

\section{First Student}

Interviewer: does your lecturer never give you such this thing in your listening class?

Respondent : he gives us such recorded audio everytime he goes into our listening class

Interviewer: Let me tell you, it is called an authentic listening material. Do you like it?

Respondent: I will like it if the listening material is not so difficult, but I like the way my lecturer teaches us...

Interviewer: O..yeah...

\section{Second Student}

Interviewer: does your lecturer give you such this recorded audio in your listening class?

Respondent: Yes, sure. He gives me the recorded audio spoken by native speaker. Interviewer: you know, it is called an authentic listening material. Do you like it? Respondent: Yes, I do. I like it, although sometimes I have to work hard for it 


\section{Third Student}

Interviewer : Have you heard such this recorded audio in your listening class?

Respondent: Of course, when we have the listening class, my lecturer always turns on such recorded audio.

Interviewer: it is called an authentic listening material. You know, do you like it?

Respondent: Yes, I like it, it is good for us to practice listening the authentic listening materials

Most students have positive attitude when they are exposed to the authentic

listening materials. They realize that

\section{First Student}

Interviewer : do you think, is it important to have authentic materials in your listening class?

Respondent : may be yes... but I need more time to listen it Interviewer: How many times? Twice? Three times? Or more?

Respondent: three times, I will be glad if it is three time.. but it is impossible, it spends too much time.

\section{Second Student}

Interviewer : do you think, is it important to have authentic materials in your listening class?

Respondent : yes, I think so... but we usually need a repeating and my lecturer gives me once or twice...

Interviewer: How many times? Twice?

Respondent: yes, twice...

\section{Third Student}

Interviewer : do you think, is it important to have authentic materials in your listening class?

Respondent : of course, sir... it is very important to us, the authentic materials are important for us to improve our listening skill

Interviewer: don't you have a repeating session, while you're listening the material?

Respondent: yes, once or sometimes twice or three times. It depends on the level of difficulties of the materials 


\section{DISCUSSION}

Huang et.al., (2011) pointed out that utilizing a wide range of authentic, meaningful activities which maximize student engagement and foster connections ro real-world contexts and situations. These activities span a broad spectrum of work and life situations as revealed by the five thematic categories of employment, technology, consumer goods, consumer servies, and citizenship/civic participation. In line with that, based on the elicited questionnaire distributed to the EFL students, it revealed that most of the EFL students like to listen any English materials. They usually enjoy English materials in the forms of films, music shows, news, comedy, especially when the students are at home or outdoors. Most of them prefer watching English films and music shows. It is implied that most of them are frequently exposed by any authentic English utterances beyond the classroom. The implicit exposure may help them relatively in grasping information from English utterances and support the atmosphere in developing their motivation in learning. Further, Coppens et.al., (2013) found out that the richness and variety of the authentic material used on the blogs and the degree of innovation applied to adapting ICTs and Web 2.0 tools to teaching EFL shown by EFL bloggers demonstrates the potential that has been unleashed with the democratization of information production.

Murray (2015) found out that all EFL teachers, despite differences in their teaching experiences and academic degrees all fully advocated using authentic materials in language classes. Teachers preferred to using authentic materials as they realized that using authentic materials would expose students to the everyday real language, as used in the daily life language. In line with Murray's findings, it is found out that with more than half of the class members voted 'agree' that the title selected by the lecturer is interesting. Most of the students noted that the class activities carried out by the lecturer are interesting. To accomodate the descrepencies between low, medium, and high achievers in learning activities, the lecturer often instructs them to work in pairs or group in solving the problems, and half of the class members 'agree' that it is good for them, they can solve the problem better in groups or pairs. Omid (2016) clarified that Iranian teachers had positive attitudes toward providing authentic input in their classes regardless of their teaching 
experience, and academic degree. He added that such an attitude was to motivate the students to improve their skills and to the real English language. When they were asked whether they enjoy the listening materials uttered by native speakers, more than half of the students feel enjoyable when their listening class using the materials in the learning activity, however, they like the way the lecturer manage the class as they mentioned that they mostly like the instructional activities.

\section{CONCLUSIONS}

The present study investigated about the students' attitudes and perceptions toward the use of authentic materials in EFL listening comprehension class. The study involved 23 EFL students who are studying in English language teaching department in Universitas Muhammadiyah Metro. The result of the study shows that most of the students know implicitly about authentic material definition and they are able to show some examples of authentic materials which usually enjoyed by the students in classroom or beyond the classrooms. The students are mostly familiar with many kinds of authentic materials which can be seen in youtube.com. Most of the students love to watch English films, music shows, comedy, sports and news and information. They sometimes use their vacant time to watch online the authentic materials in youtube. The EFL students understand that by exposing themselves to any kinds of the authentic materials in youtube.com, they are encouraged to practice their listening comprehension by using youtube authentic materials. Most of them show positive attitudes and good perceptions toward the use of youtube authentic materials for practicing their listening comprehension.

\section{SUGGESTIONS}

Future researchers are suggested to discover more interesting topics which preferred by youngsters in developing their listening comprehension. Youtube or another open source video internet providers have shared freely a lot of interesting authentic 
resources. The instructors need to select the materials to match the students' proficiencies. By addressing the topics preferred by the EFL students can trigger their curiousity to comprehend the content of the topics. However, giving the topic preferred only by the lecturer may weaken the students' motivation to practice and comprehend listening

\section{BIOPROFILE}

Refai is an English instructor at the English Department of Muhammadiyah University in Metro Lampung Indonesia. He has finished his master degree on English Pedagogy from State University of Malang. Now, he is pursuing his study in the State University of Malang for his doctoral degree. His expertises are in English Language Teaching, listening, and reading comprehension. Corresponding email: refaiummetro@gmail.com 


\section{REFERENCES}

Abidin, M. J. Z (2012). EFL Students' Attitude towards Learning English Language: The Case of Libyan Secondary School Students. www.ccset.org/ass, 8(2): 119-133

Ahmed, Shameem (2015). Attitudes toward English Language Learning among EFL learners at UMSKAL. Journal of Educationa and Practice. 6(18), 6-16. [Online] Available: www.iiste.org.

Akbari, Omid \& Razavi, Azam. (2015). Using authentic materials in the foreign language classroom: Teachers' perspective in EFL classes. International Journal of Research Studies in Education, 5(2): 105-116.

Buck, G. (2001). Assessing listening. Cambridge: Cambridge University Pres

Cahyono, B.Y. \& Widiati, U. (2009). The Teaching of EFL Listening in The Indonesian Context: The State of The Art. TEFLIN Journal, 20(2): 194-211

Hedge, T. (1985). Using readers in language teaching. London: Macmillan

Goh, C. (2002). 'Exploring listening comprehension tactics and their interaction patterns'. System 30(2): 185-206

Gardner, R.C (1985). Social psychology and second language learning: The Role of Attitudes and Motivation. Beltimore, Maryland, U.S.A: Edward Arnold (Publisher)

Ghaderpanahi, Leila. (2012). Using authentic aural materials to develop listening comprehension in the EFL Classroom. Canadian Center of Science and Education. ELT: 5(6): 146-153

Polio, Charlene. (2014). Using authentic material in the beginning language classroom. Center for Language Education and Research, 18(1): 1-8

Renandya. A. Willy \& Farrell. S.C. Thomas. (2011). Teacher, the tape is too fast! Extensive listening in ELT. ELT Journal, 65(1): 52-59.

Richard, C. Jack. (2008). Teaching Listening and Speaking: From Theory to Practice. New York: Cambridge University Press.

Tavil, Z. (2009). Parental Attitudes towards English Education for Kindergarten Students in Turkey. Kastamonu Education Journal. 17(1), 331-340. [Online] Available: www.kefdergi.com/pdf/cilt17_no1/331.pdf (August 9, 2011)

Premise Journal Vol 7 No 1, April 2018, e-ISSN: 2442-482x, p-ISSN: 2089-334, page 22-35 Copyright@2018 by PJEE 